\title{
Taiwanese Graduate Students' Personal Experiences on Culturally Related Language Anxiety and Adjustment
}

\author{
Yi-Wen Huang ${ }^{1}$ \\ ${ }^{1}$ University of New Mexico-Gallup, USA \\ Correspondence: Yi-Wen Huang, Division of Arts \& Sciences, University of New Mexico-Gallup, 705 Gurley \\ Ave., Gallup, NM 87301, USA. E-mail: yhuang75@unm.edu
}

Received: March 16, 2014

Accepted: April 9, 2014

Online Published: April 25, 2014

doi:10.5539/jedp.v4n1p258

URL: http://dx.doi.org/10.5539/jedp.v4n1p258

\begin{abstract}
This study aims to understand Taiwanese graduate students' personal experiences with culturally-related language anxiety and adjustment in academic settings and utilizes an adapted version of FLCAS (Horwitz, Horwitz, \& Cope, 1986), in-depth interviews, and focus groups. The results suggested that these Taiwanese graduate students' primary issues associated with culturally-related language anxiety and adjustment are listening comprehension, participation in group discussions, and Taiwanese students' mixed feelings among members of the same nationality.
\end{abstract}

Keywords: attitudes, competition, cultural adjustment, cultural components, culturally-related, group discussion, language anxiety, listening comprehension, Taiwanese students

\section{Introduction}

International students studying abroad face not only the challenges of the target language but also the culture of the classroom in a foreign country. Most of the international students who just arrive are worried about comprehending their professors' lecture and accomplishing the assignments. However, in order to succeed they need to adjust to the classroom culture in the foreign country. Many factors in the previous literature have been found to be associated with language anxiety in academic settings. However, few studies (e.g., Lim, 2009; Stroud \& Wee, 2006) have examined cultural components and their relationships to language anxiety in these contexts. In Lim's (2009) study, Asian learners of English, especially Korean, Chinese, or Taiwanese, were found to have experienced higher language anxiety than learners from other countries. Also, the majority of the previous studies were investigated in quantitative methods, only a few in qualitative methods.

Young (1999) stated that since the 1990s, researchers have conducted plenty of research on language anxiety in foreign language or second language learning. The first book-length treatment of language anxiety by Horwitz and Young appeared in 1991. Most previous studies on language anxiety have utilized quantitative methodologies. These quantitative studies on language anxiety may not consider language learners as individuals "with something to say and the ability to say it with force and clarity" (Cohen \& Norst, 1989, p. 66). Since language anxiety involves language learners' psychological reactions to the language learning situation, many questions related to learners' experiences are not easily investigated by quantitative methods. Previous qualitative research on language anxiety has provided deep insights on some aspects of language learners' personal experiences in this area (e.g., Bailey, 1983; Price, 1991). These have been very helpful for instructors and language learners in their desire to understand language anxiety as the set of mixed feelings associated with FL or SL learning.

\subsection{Definition}

Many definitions have been offered for language anxiety in the previous literature. MacIntyre (1995) stated that language anxiety is triggered by aspects of communicative and social contexts, so it can be defined as a social anxiety (p. 90; MacIntyre \& Gardner, 1991). Similarly, in Young's (1990) study, she mentioned that social anxiety might be related to language anxiety. Young (1990) suggested that her subjects' "reactions to error correction" (p. 550) show that social anxiety may be another component in language anxiety (p. 550). Students' fear of being judged or negatively evaluated by their classmates in class produces social anxiety (Young, 1990). Young (1990) reported that "communication apprehension, social anxiety, and low self-esteem are vital 
components of language anxiety" (p. 550). Pappamihiel (2002) described language anxiety as social anxiety dependent on the learner's interactions with the target language speakers.

Leary (1982) stated that social anxiety may be referred to as embarrassment, shyness, stage fright, fear of evaluation, or communication apprehension. An individual who has experienced social anxiety might avoid or withdraw from social situations. Communication apprehension has been linked to language anxiety, in studies such as Horwitz, Horwitz, and Cope's (1986) study which identified fear of negative evaluation, communication apprehension, and test anxiety as factors linked to foreign language anxiety. McCroskey (1977) viewed communication apprehension as an individual's fear or anxiety related to either real or anticipated communication with one person or a group of people.

A foreign student's native culture may be associated with communication apprehension. Klopf (1997) and Wong-Scollon and Scollon (1990) portrayed Chinese people as silent and not attempting to dominate or be subordinate in conversation in social situations because Chinese culture demands respectful participation. Also, based on Wong-Scollon and Scollon's (1990) notion of "the flow of talk" (p. 288),"exchanges of turns" (p. 288) are different between Chinese conversation and English conversation. Therefore, Chinese speakers feel that they cannot accurately assess English speakers' responses in social situations. Moreover, their lack of fluency in English and English speakers' failure to provide traffic signals to let them proceed in the conversation makes Chinese speakers confused (Wong-Scollon \& Scollon, 1990). Hu and Grove (1991) stated that Chinese tradition values humility by using honorifics and self-deprecating terms to demonstrate "the absence of self-centeredness and personal assertiveness" (p. 54); however, Americans seem to find this linguistic style to be self-disparaging. The Chinese are taught at a very young age to "enhance harmony and avoid friction" (p. 54), and "to keep themselves in check, and to be tolerant" (p. 54).

Horwitz et al.'s (1986) study concentrated on foreign language classroom anxiety (FLCA). Horwitz et al. (1986) stated that the concept of language anxiety is not appropriately defined, and that the effects of language anxiety on language learning are not clear. Hence, they simply defined language anxiety as a unique experience while learning the target language or as a manifestation of other general types of anxiety. Gardner and MacIntyre (1993) defined language anxiety as "the apprehension experienced when a situation requires the use of a second language with which the individual is not fully proficient" (p. 5). MacIntyre (1999) concluded in a like manner, defining language anxiety "as the worry and negative emotional reaction aroused when learning or using a second language" (p. 27). Thus, MacIntyre (1999) defined that "language anxiety is a form of situation-specific anxiety" (p. 29).

\subsection{Factors}

Perfectionism can be a source of language anxiety. FL or SL students may experience high level of language anxiety in class because they are too concerned about performing without flaws - for example, they hear their accents when speaking the target language, and they are embarrassed or feel foolish because of making mistakes (Price, 1991, p. 106; Gregersen \& Horwitz, 2002, p. 568; Hilleson, 1996).

Learning experiences could be a factor as well. Some previous literature (Aida, 1994; Clément, Dörnyei, \& Noels, 1994; Hewitt \& Stephenson, 2012; MacIntyre, 1999; Young, 1999) considered that language anxiety is a situational-type of anxiety because of learning experiences. Language anxiety develops as a result of "repeated, negative experiences" (Gardner \& MacIntyre, 1993, p. 6) encountered in the processes of L2 learning. Language anxiety might thus be a "learned emotional response" (Gardner \& MacIntyre, 1993, p. 6). MacIntyre and Gardner (1991) found that language anxiety is related to students' experience with and achievement in FL learning. Also, Hewitt and Stephenson's (2012) study suggested that the participants' educational background - one with little emphasis on oral skill - may have contributed to their anxiety in oral exams (p. 184).

Gender could be a factor as well. In Mesri's (2012) study on Iranian undergraduate students' FL classroom anxiety and gender, the results suggested that male students are less anxious than female ones. However, this finding is inconsistent with Mills, Pajares, and Herron's (2006) study on undergraduate students enrolled in French classes, which the results suggested that FL listening anxiety is positively associated with both male and female students' listening proficiency.

Achievement can also be a factor. MacIntyre and Gardner (1991) found a negative relationship between French Class Anxiety, achievement, and experience in language learning. According to their research in a French-intensive summer school, English speaking students' increased achievement and positive experiences lowered their French Class Anxiety (p. 111). Also, in Hewitt and Stephenson's (2012) replication of Phillips's (1992) study on university students whose native language is mainly Spanish, enrolled in an elective English 
class, the results generally confirmed Phillips's findings that L2 anxiety associated negatively with oral exam performance.

In addition to cultural factors such as students' native culture (Stroud \& Wee, 2006), language anxiety has been found to be associated with relationships or social interactions with the target language speakers (Aida, 1994; Mak, 2011; Pappamihiel, 2002). In Pappamihiel's study, the ESL Mexican students' language anxiety came from their belief that they were being looked down upon by Mexican American students. Based on this study, she concluded that language anxiety can be described as social anxiety.

Besides all of the factors mentioned above, many other factors such as learners' self-confidence (Clément; 1980; Casado \& Dereshiwsky, 2004), language self (Horwitz, et al., 1986), tolerance of ambiguity (Ehrman \& Oxford, 1995), unwillingness to communicate (Liu \& Jackson, 2008), fear of speaking (Horwitz et al., 1986; Mak, 2011), attitudes toward language classes (Aida, 1994; Mak, 2011), fear of failing the language class (Aida, 1994; Mak, 2011), teachers' attitudes or characteristics (Young, 1990), teaching pedagogies (Suwantarathip \& Wichadee, 2010; Young, 1990, 1999), etc., are all found to be associated with FL or SL anxiety.

\subsection{Cultural Components/Adjustment}

Sojourners might experience difficulties adjusting to such issues as role behavior, role expectations, social distance, dealing with conflict, or non-verbal communication or symbols in a foreign country (Gullahorn \& Gullahorn, 1963). For example, due to Confucianism, teacher-student relationships in Taiwan are more authoritarian than in America. Taiwanese students might experience difficulties interacting with their American professors at an American campus. Klein et al. (1971) pointed out that several barriers between Asians and Americans exist. First, their social behaviors are different. Relearning the social behaviors is necessary to adjust to American society. Second, more importantly, Asians or Asian students might have to adjust to the new social roles and therefore, experience emotional problems because of basic functional differences. The barrier that Asian students fear the most is the loss of the familiar social structure and supportive peer network after arriving in the U.S. (Klein et al., 1971).

Due to language barriers, foreign students may feel stressed when adjusting to the target culture. Based on Constantine, Okazaki, and Utsey's (2004) study on African, Asian, Latin American students studying in the U.S., the results suggested that the greater the English fluency, the lower the depression scores, and acculturative stress is positively related to depression. Likewise, in Wang and Mallinckrodt's (2006) study, Chinese/Taiwanese international students' self-perceived language proficiency was negatively associated with socio-cultural adjustment and psychological distress.

East-Asian students' apparent silence is associated with two main factors: (a) "language communication competence," and (b) "cultural differences from the mainstream Euro-American societies" (Zhou, Knoke, \& Sakamoto, 2005, p. 288). Also, due to Confucianism, modesty is strongly valued in Chinese and Taiwanese cultures; therefore, Chinese students do not tend to dominate discussions in class because that might be considered showing off by Chinese peers. For example, one of the Taiwanese students in the study of Martin and Nakayama (2008) stated that

In America, sometimes students talk half of the class time. Compared to my classes in Taiwan, if a student asked too many questions or expressed his or her opinions that much, we would consider the person a show-off or insincere. Consequently, this is one of the difficulties I have experienced because of differences in culture. (p. 134)

Kim (2002) stated that silence has not been explored in sociolinguistics and communication studies. Americans prize assertiveness or speech but Japanese, Korean, or Chinese highly value silence. Western cultures, which value independence, view silence as impolite or negative in many ways such as embarrassment. However, in East Asian countries, communicators who emphasize silence are viewed as competent and mature communicators (Kim, 2002).

According to Hall's (1976) theory of high or low context, Chinese, including Taiwanese, is a higher-context culture than the U.S which is low in context. As a result, Taiwanese students rely much more on nonverbal communications than American students.

Few studies in the past have investigated how social interactions and foreign students' native cultures associated with language anxiety; therefore, these factors should be taken into account when investigating international students' language anxiety in academic settings. Since they have to adjust to the academic culture in U.S. classrooms, cultural adjustment or components should also be examined in the study of language anxiety. 


\section{The Research Design}

The present study is characterized as a qualitative multicase study. The adapted version of the FLCAS is an instrument to filter the participants' level of language anxiety as a preliminary method. Qualitative methodology is utilized to obtain participants' insights in one on one specific feature, which cannot be obtained through the questionnaire. Pavlenko (2002) emphasized that L2 learners' personal narratives are extremely important in the TESOL field because the learners', the teachers', and the researcher's voices can be heard as each position holds its own perspective on the process of learning the target language (p. 214). Qualitative research is subjective, private and personal, and the qualitative researcher, in Stake's (1995) terms, "promote[s] a subjective research paradigm" (p. 45). Stake (1995) stated "[t]he real business of case study is particularization, not generalization. We take a particular case and come to know it well, not primarily as to how it is different from others but what it is, what it does" (p. 8), which means that qualitative case study is very much a personal study.

The design of this study includes triangulation to reduce the risk that the conclusions of the study would not be valid or to reduce the researcher's biases and the limitations of the study (Maxwell, 1996, p. 75). Triangulation is the application of multiple methods to solve a research problem "as a method of validation" (Denzin, \& Lincoln, 2003, p. 423), which can help researchers better understand the participants' stories (Fontana \& Frey, 2003).

\section{Method}

\subsection{Setting}

The study took place at a mid-sized Midwestern university in the U.S. which is located in a small town featuring a relatively homogeneous local population.

\subsection{Participants}

These participants were Taiwanese graduate students studying in an American university, who have at least completed high school and learned English as a foreign language while residing in Taiwan.

\subsection{Questionnaire}

The adapted version of Foreign Language Classroom Anxiety Scale (FLCAS) by Horwitz, Horwitz, and Cope (1986) was administered as a preliminary measure of language anxiety. It is a self-report questionnaire, and its purpose is to examine students' foreign language anxiety in the classroom. Two adjustments were made to the questionnaire. One item was added to examine professor-student interaction. Also, the phrase foreign language was adapted to English and foreign language classes was adapted to classes in the U.S., to reflect the setting of this study. In item 11 on the questionnaire, the participants were told that the category English classes consist of all the classes they have taken in the U.S. One text open-ended questionnaire item 34 was added to FLCAS which is "Talking to my professor is __." When the questionnaire and open-ended statement indicated that they had experienced some level of language anxiety, the participant was invited to participate in three in-depth individual interviews.

\subsection{Pre-Interview Writing Exercise}

Before individual interviews, the participants were asked to write pre-interview writing exercises in order to help understand their experiences in the U.S. classrooms. Questions included participants' experiences in their first class in the U.S., present feelings in class, and progress in English use. Participants were given a demographic information sheet which included a self-rated English proficiency as well.

\subsection{Three In-Depth Individual Interviews}

According to Swagler and Ellis's (2003) concept of neutralization, it was especially important to inform the participants that negative experiences are welcome as well. Also, personal comments were not provided while making efforts to listen to the participants' personal experiences in accordance with Patton's (1990) notion of empathic neutrality. These interviews were semi-structured and open-ended. Each interview took approximately one hour and thirty minutes.

\subsection{A Focus Group Interview}

All of the participants from the interview stage were invited to come and meet one another. The purpose of this group interview was to confirm or clarify the responses obtained from the individual interviews and to probe for information which might not have otherwise been revealed during the individual interviews. Most importantly, the participants were asked to restate or summarize the significance of their experiences (i.e., their thoughts and feelings) on the research topics. Krueger (1993) reported that having the respondents summarize their points of 
view toward the critical topics at the end of the discussion could be beneficial. The discussion lasted approximately one hour and thirty minutes.

\subsection{Cross-Case Analysis}

Merriam (1988) pointed out that the analysis of a single case is the same as the multicase one which better increases the possibility of generalization than a single case. Also, Merriam (1988) stated that in the process of analysis, common themes can be developed, so the relationships among variables can be specified in order to reach a higher level of analysis. In the current study, patterns or common themes were found and coded based on the interview and focus group transcripts.

\section{Questionnaire Results}

According to the Taiwanese Student Association, there were approximately twenty-five Taiwanese graduate students studying at this American university, and among these, twenty students' contact information was provided by the president of Taiwanese Student Association. A total of twenty Taiwanese graduate students were invited to fill out the adapted version of the FLCAS, and eighteen-7 males and 11 females - accepted the invitation. The scores were calculated by adding up the total and dividing it by 33 , the total number of items, and reverse-scoring items that need to be reverse-scored. Among these eighteen, only one participant's score was near 4 indicating a high level of anxiety; six participants' scores were around 3.5; five participants' scores were around 3 and below 3.5; and six participants' scores were below 3 indicating a low level of anxiety. Based on the results of the adapted FLCAS, the participants were found to be more worried about being prepared for class and speaking when they were called on in class. They were found to be more nervous in class in the U.S. than in Taiwan and be worried about failing classes in the U.S. They did not report anxiety over speaking with native speakers on the questionnaire.

\subsection{Open-Ended Question}

\section{Talking to my American professors is}

Responses were mixed. (7/18) Seven of the participants reported that talking to their American professors "terrifies" them,"'takes] courage," is "nerve wracking," "embarrassing," is "like to talk to [talking to] your boss," or makes them "nervous." (6/18) Six of the participants reported that talking to their American professors is "always a pleasant experience," "okay," "good experience," "very usual," and "relax[ing]."

\section{Overview of Participants}

Except for the 4 respondents whose adapted FLCAS scores were the lowest, fourteen participants (4 males, 10 females) whose scores indicated having experienced some level of language anxiety (from high anxiety to low anxiety) were invited to take part in the interview phase of the study. Eleven accepted. One withdrew (female, slightly low anxious), leaving ten ( 2 males, 8 females) to parttake in the study all the way through. All of these ten interview participants were invited to participate in the focus group meeting. 1 males and 5 females showed up for the meeting. Table 1 shows these ten participants' levels of language anxiety from high to low based on adapted FLCAS, self-rated English proficiency, and length of stay in the U.S. prior to the study. Table 2 shows their demographic information including gender, age, major, profession prior to studying in the U.S. Participants' names are listed as pseudonyms.

Table 1. Adapted FLCAS, self- rated English proficiency and length of stay in the U.S

\begin{tabular}{llll}
\hline Participant & Anxiety level & Self-rated English Proficiency & Length of Stay \\
\hline $\mathrm{Ai}$ & high & intermediate & 6 months -1 year \\
$\mathrm{De}$ & slightly high & advanced & 4 years \\
$\mathrm{Bao}$ & moderately & poor & 1.5 years \\
$\mathrm{Chan}$ & moderately & intermediate & 6 months- 1 year \\
Dai & moderately & fair & 1 year \\
Hua & moderately & advanced & 10 years \\
Jiao & slightly low & advanced & 3 years \\
Ming & slightly low & fair & 6 months -1 year \\
Ya & slightly low & advanced & 2.5 years \\
Lan & low & intermediate & 4 years \\
\hline
\end{tabular}


Based on Table 1, participants' levels of anxiety on the adapted version of FLCAS are not consistent with self-rated English proficiency and length of stay in the U.S.

Table 2. Participants' demographic information

\begin{tabular}{|c|c|c|c|c|}
\hline Participant & Gender & Age & Major Program & Profession \\
\hline $\mathrm{Ai}$ & $\mathrm{f}$ & $\operatorname{mid} 30 \mathrm{~s}$ & Eng Ph.D. & post-secondary Eng instructor \\
\hline De & $\mathrm{m}$ & $\operatorname{mid} 40 \mathrm{~s}$ & Eng Ph.D. & post-secondary Eng instructor \\
\hline Bao & $\mathrm{f}$ & $\operatorname{mid} 20 \mathrm{~s}$ & MBA & assistant \\
\hline Chan & $\mathrm{f}$ & early 30s & Sports MA & not disclosed \\
\hline Dai & $\mathrm{f}$ & mid 20s & MBA & not disclosed \\
\hline Hua & $\mathrm{f}$ & $\operatorname{mid} 30 \mathrm{~s}$ & Eng Ph.D. & $\begin{array}{l}\text { private language institute } \\
\text { instructor of Eng }\end{array}$ \\
\hline Jiao & $\mathrm{f}$ & $\operatorname{mid} 20 \mathrm{~s}$ & Eng Ph.D. & none \\
\hline Ming & $\mathrm{m}$ & early $30 \mathrm{~s}$ & MBA & not disclosed \\
\hline Ya & $\mathrm{f}$ & $\operatorname{mid} 30 \mathrm{~s}$ & Eng Ph.D. & post-secondary Eng instructor \\
\hline Lan & $\mathrm{f}$ & $\operatorname{mid} 20 \mathrm{~s}$ & Eng Ph.D. & none \\
\hline
\end{tabular}

\section{Pre-Interview Writing Exercise}

The interview participants were asked to write one paragraph reflecting on their progress in class: their experiences during their first class in the U.S., their present feelings in class, and their current progress in English use. Written responses were given in English.

First Class in the U.S.

(6/10) Six of the ten participants reported that they felt "nervous," (Chan) (Lan) (Jiao) "disoriented," (De) or "frustrated," (Ai) (Lan) in their first classes in the U.S. because of the problems understanding their professors" and American classmates' English, and adjusting to the classroom formats-especially group discussions.

\section{Present Feelings in Class}

(4/10) Four of the ten participants answered that they now feel "more comfortable," (Ai) (Ya) (Jiao) or have gained "confidence" (Lan) when speaking English in class discussions or group discussions. However, (1/10) one of the participants, Jiao reported that currently she "still struggle[s]" to "give academic speeches or personal opinions or ideas" in class.

\section{Progress in English Use}

(4/10) Four of the participants reported that their listening comprehension has improved, offering comments such as "I can understand the lectures better" (De). (4/10) Four of the participants reported that their English speaking or communication has improved. (2/10) Two participants specifically cited interactions with the target language speakers as having improved their English fluency.

\section{Results from the Interviews and Focus Group}

The interviews were all conducted in Mandarin Chinese. The responses quoted have been translated from the originals. The following are the common themes analyzed from the individual interviews and focus group interview transcripts:

1. Problems with listening comprehension, 2. fear of speaking in class, 3. participation in group discussions, 4. perceived attitude of American professors, 5. perceived American professors' attitudes, 6. Taiwanese educational background, and 7. Taiwanese students' mixed feelings among members of the same nationality.

\subsection{Problems with Listening Comprehension}

$(10 / 10)$ Virtually all ten participants spoke of difficulty understanding what is said during their classes, and some identified this problem as a source of anxiety. Ai described her listening comprehension problem in class and her reaction to this situation: "I cannot comprehend most of the time in class. I must ask classmates what is due next week, which makes me feel frustrated ... In the beginning, I was very nervous. I was completely lost.” After 
noting that her comprehension problem still troubles her today, she went on to compare her previous experience in Taiwan to the frustration she now experiences, noting that this has caused her to realize she needs to lower her current expectations:

When I was a student in Taiwan, I thought that I needed to comprehend one hundred percent! So, this is my first time studying in the U.S., and I realized that I will never be able to comprehend one hundred percent.

Even when she knows which assignment will be due next class, she still faces insecurity or anxiety over her level of listening comprehension:

I ask foreign students what is due next time after every class. I make sure that I know what is due next time and what I need to do for the next class ... Even though I may know which assignment is due in the next class, I will still ask classmates to make sure whether or not I am wrong because I don't have confidence in my [listening comprehension] ability.

Ai stated that she hopes that someday she will be able to comprehend everything when listening to English, but she also tells herself that "it takes time, and there is no shortcut." In the meantime, she is "very frustrated," and she feels at times discouraged about her decision to come to the U.S.:

In group discussions ... I feel very frustrated because I still cannot completely comprehend everything in the target language. If I cannot completely comprehend, I lose my confidence, and I feel that I should have just studied in Taiwan instead.

Ai has experienced a strong level of language anxiety especially over problems with listening comprehension during class lectures and group discussions, and this anxiety is associated with the high standard she holds for herself.

\subsubsection{Speech Rate}

(4/10) Four of the participants cited comprehension problems due to native speech rates. After studying in a language institute in another state in the U.S., Dai stated that her teachers at language school had tended to speak slowly in class, but when she enrolled as a graduate student, her professors didn't slow their speech rates when they spoke: "The professors used normal speech rate to talk in class. The professors spoke faster, so I could not understand the lecture! I didn't get the points, so I was scared that those would be in the exams!"

Although Jiao overcame her difficulties understanding her professors' lectures, she still has problems understanding her American classmates' speech in class. She claimed that 'in the beginning, it was very difficult to understand the professors' lectures. Later on, that turned out to be the easiest part. However, the communication between me and my classmates [American students] was more difficult because they all spoke very fast."

Generally, these participants seemed to feel that their listening problems were improving over time, though they have not been resolved especially when interacting with American students. For instance, Ai confirmed that she is "still nervous in class" despite her improvement.

\subsection{Fear of Speaking in Class}

$(5 / 10)$ Five participants claimed that they have experienced anxiety over speaking in class. Four (Ming, De, Chan, and Ya) spoke as if this anxiety is as present now as it ever was. One participant (Jiao) spoke of continuing anxiety, though she felt it had somewhat lessened. Only one participant, Lan, who scored the lowest among these 10 participants on the questionnaire, claimed to have entirely overcome this problem.

The unfamiliar and nervous feelings with almost all American students in group discussions and American classmate's fast pace of discussion and speech rate contributed to her early apprehension in speaking in class. Lan claimed that "in the beginning, I was afraid to speak in class because most of the students in class are Americans ... so they discussed the topics very quickly. As a result, I usually was lost or unable to cut in to their discussion." Lan claimed to have experienced language anxiety during group discussions.

\subsubsection{Fear of Making Errors in Speaking}

(3/5) Three participants claimed to be apprehensive about making errors when speaking in class. De is ambivalent about his oral classroom performance. He claimed that he has no problem expressing his ideas in English, but at the same time, he admitted that he is "scared to speak the wrong words" in class, which limits his participation. Chan claimed that if she is not sure what to say, she will choose not to speak. She described the mental process she goes through when deciding whether or not to speak in a group discussion: 
Before I speak, I will think about it. Is it okay if I say this later? Then, I will hesitate, if I am not sure then I won't speak! If I have already thought through what I want to say, then, I will decide to, will speak on this point next!

\subsubsection{Fear of Being Called On}

(2/5) Two participants, De and Ya, explicitly reported their fear of being called on in class. They both remain unable to overcome this problem. De is very nervous when the professors directly ask students to answer questions or require students to participate:

I hardly ask questions or speak my own opinions in class. If I just listen in class, I won't feel that nervous. But, if professors require us to participate, I feel a lot more nervous ... I am more used to listening to the lecture in class, so if the professors call on me directly, I feel uncomfortable ... I am the most nervous when the professors are asking questions in class.

\subsection{Participation in Group Discussions}

(9/10) Almost all of the participants claimed that they had a hard time adjusting to group discussions in U.S. classes - especially during the first semester. Chan still cannot overcome this difficulty and has experienced high anxiety over this, claiming that she becomes "really nervous" and that group discussions give her a "serious headache." Commenting further, Chan emphasized that class participation as a concept does not exist in Taiwan:

Group discussion is nothing, but every time there is a group discussion, I start to become very nervous! Because ... in Taiwan, we don't have group discussions. I have never had this experience, so it makes me really nervous.

She claimed that she feels lost in this unfamiliar format: "I don't know what to say. I don't know what they [American classmates] said. I only listen! Sometimes, I speak a little bit—one or two sentences!" She stated that group discussion makes her feel really anxious due to both her inexperience in group discussions and her lack of knowledge of the course content:

So, I was there [in class], really nervous in a group discussion. What will my professor ask us to discuss? ... Every time I thought about the fact that I had to participate, I started to have a serious headache! What do I need to say? I started to have a headache.

Far from seeing these discussions as a kind of non-threatening collaboration, Chan feels threatened and worried that some inadequacy in her knowledge may be revealed.

Similarly, after studying in the U.S. for two semesters, Ai stated that she still feels "frustrated" participating in group discussions for reasons having to do with her perception of her American classmates' behaviors and views:

I used to think that after finishing the assigned reading, I was looking forward to participating in the group discussion ... and then, they [American students] would speak very fast. It is hard for you to interrupt them, and they don't have much patience with you. They think that you are just a listener. After they talk a lot and are tired, you can get a word in ... When they are talking between one another, it is very difficult to interrupt them.

Almost all of the participants claimed to experience this high level of anxiety right before or during group discussions due to many reasons including Taiwanese educational background, listening comprehension, course content, and perceived American students' attitudes, and unfamiliarity with or lack of proficiency in turn-taking in Western communication.

\subsection{Perceived American Classmates' Attitudes}

(5/10) Five participants reported that American classmates' attitudes/eye contact constitute a source of anxiety in class. Even though most of the participants experienced difficulty adjusting to the group discussions in class, De was also simultaneously "scared" to be left out of the group as a second language speaker. He felt "uncomfortable" that the American students only seemed to form groups with other American students. Dai claimed that "American classmates won't take the initiative to talk to you." Hua stated that this is the situation with American students which upsets her the most: “ ... especially if there are only two or three international students, American students hardly give us opportunities to speak because, while you are speaking up in class, they will cut you off." Again, turn-taking is an important factor. As mentioned earlier, the Chinese students expect respectful participations in conversations. Wong-Scollon and Scollon (1990) stated that Chinese speakers' lack of fluency in English and English speakers' failure to explicitly signal turns during conversation can lead to confusion on the part of Chinese speakers. 
It is worth noting that eye contact, too, was a recurring theme in connection with the issue of Americans' attitudes. Lan cited one particular case, which took place during a group discussion:

We were in a group discussion, and he [an American student] never turned his head and looked at me when I talked. He simply refused to look at me when I spoke. He never spoke to me in class or outside the class. It made me feel really upset.

Lan's reaction is understandable. During group discussions, the Chinese expect others in the group to have minimal eye contact with them and signal turns for each of the group members to speak, not ignoring them. However, group members should maintain some eye contact, but not intense eye contact, which is a social taboo in Chinese communication. For example, Chan claimed that she can feel her American classmates' attitudes toward her through their eyes: "Americans think that they are very smart. I can tell from their eyes, and the way they talk." She seemed to view her American classmates' pattern of eye contact, which she deems too intense and to be the equivalent of a nonverbal insult.

\subsection{Perceived Attitudes of American Professors}

(4/10) Four of the participants expressed their disappointment, anger, or anxiety towards their professors in the U.S. Jiao spoke of two of her American professors' attitudes toward "international students": "Probably, he thinks that you are not good enough to be doctoral students, so his attitudes are horrible!" She continued,

She is not very friendly to international students! She thinks that we, as high-level students, should not have such low performance ... They made me feel really humiliated. Am I really that bad?

Ai believes that her "strong anxiety" is related to her "professors' attitudes" toward "ESL students" — in other words, whether or not the American professors will accept them as target language learners, as opposed to native speakers. As the interview progressed, she stated that

My anxiety is related to the professors' attitudes ... It is not that they are strict. It's their acceptance. I think that my anxiety is associated with my professors' acceptance of ESL students. If I'm in a class where I feel the professor considers non-native speakers as being second-class, I will feel strong pressure and experience anxiety.

These participants are very anxious about whether or not their professors accept them as ESL students. Also, they hope that their professors will show empathy toward them in their situation as international students.

\subsection{Taiwanese Educational Background}

(5/10) Five of the participants claimed that their Taiwanese education has had a great influence on their language anxiety and adjustment to American classroom practices. Noting that this is not their first time studying in the U.S., De, Chan, Jiao, and Dai have all claimed to still experience difficulties and anxiety with listening comprehension or participating in group discussions due to what they consider a lack of training in Taiwan. De indicated that "listening is my weakest ... I haven't received enough training in listening because we were trained more in reading and writing in Taiwan ..."

Chan claimed that she has experienced "strong anxiety" over participating in group discussions because her education in Taiwan did not train her to "negotiate." As a result, she stated that without having developed a "sense" of how to "negotiate" in group discussions, she must "cooperate" with her American classmates in group discussions. She conveyed that, since she had no sense of how to "negotiate" with her peers, the only strategy left for her was to "cooperate"- that is, to fit in, without feeling able to submit her own ideas to the learning process. On a related note, she stated that teachers in Taiwan do not require or encourage students to ask questions in class. However, professors here will "encourage" students to ask questions, in an environment where "American students are used to asking questions."

She then conveyed that there exist between Taiwan and the U.S. "cultural differences in the classroom." She showed puzzlement over the interactions she saw in American classrooms. She wondered why American students "disrespected" the professors by "interrupting them and asking questions while they were speaking."

\subsection{Taiwanese Students' Mixed Feelings among Members of the Same Nationality}

(7/10) Surprisingly, seven of these ten Taiwanese students have mixed feelings about members of their own ethnic group, and these feelings of fitting in, resisting, avoiding, and competing with members of their own ethnic group can contribute to their anxiety and impede their adjustment in America. Seven of the participants claimed that their adjustment has been affected by Taiwanese classmates or students, including experiencing difficulties getting along with them, based at least in part on the competitiveness that arises among Taiwanese students. Of these seven, four participants claimed to have negative attitudes toward other Taiwanese students or 
classmates. After she discussed assignments, asked for advice on which courses to take from them, or had group discussions with Taiwanese classmates outside of class, Ai expressed feeling "shocked," "the most frustrated," "confused," and "very sad." Dai feels "the most uncomfortable" about Taiwanese students who hang out in groups. Hua and Chan found themselves avoiding associating with Taiwanese students or speaking Chinese. Three participants felt more positive about their Taiwanese peers. Even though he feels competition among classmates, De claimed to get "emotional support" from Taiwanese students. Bao claimed that Taiwanese students "depend on" each other in class. Ming claimed that he looked for advice from Taiwanese sisters and brothers who came before him about what classes to take.

Ai, who scored the highest among the participants, expressed her strong feelings about Taiwanese students' competitiveness. She stated that she associates with one American classmate and has a few Korean friends, but that she does not have any Taiwanese friends in the U.S.:

I wish that I could be more accepted and could fit in better here. I wish everyone would invite me out to eat or chat with me ... I am very often a loner here. When I see negative competition between international students who are from the same country, I know this situation is weird, and I am shocked.

Ai elaborated, calling her fellow Taiwanese students "rude and aggressive," and asserting, "I cannot discuss assignments with them." Unfortunately, she claimed that she feels "the most frustrated" about the fact that her Taiwanese classmates are competing with her or other Taiwanese students:

I don't have any Taiwanese friends here because of the competition. I feel the most frustrated about competition between Taiwanese students here ... In the beginning, I was very sad ... I guess it is because we are not in our own country, we are insecure ...

The students with positive views also elaborated. On the theme of competitiveness, De said that, while he could feel the competition among classmates, he also stated that he feels he is able to receive "emotional support" from Taiwanese students, especially from those who have finished their coursework.

Dai also expressed conflicting views. She claimed that Taiwanese students have negative attitudes toward her because of her behavior. She stated that "as for me, it is true that I don't have any friends, but I don't know what the big deal is. For me, this is my life, and eating alone in the Dining Hall is nothing. I just go there to eat [not to socialize]." Dai avoided associating with Taiwanese students and disapproved of the way Taiwanese students live and hang out together as a group. However, she admitted that she still seeks advice from Taiwanese school brothers and sisters when it's time to take classes: "For example before I take any classes, I will ask my school sister [senior female Taiwanese students who have finished the course] how the class is, how the professor is, how the professor's teaching is, or what issues I need to pay attention to." Similarly, Hua claimed to avoid associating with Taiwanese students in order to "practice English." Chan offering similar comments, claimed that when she had just arrived here, she was "very nervous" because of the target language difficulty. So, she tried "not to hang out with Taiwanese students and speak Chinese", and to feel "independent." She insisted that she has to speak English. As a result, she claimed that her English has improved.

In summary, listening comprehension, participation in group discussion, and the mixed feelings towards fellow Taiwanese students were found to be the major sources of these participants' language anxiety and cultural adjustment.

\section{Discussion}

Based on the results of the study, the majority of these Taiwanese students have experienced a high level of anxiety with listening comprehension and participation in group discussions. The participants cited their perceived attitudes of American classmates such as only forming groups with other Americans, speech rate, and eye contact as one source of their anxiety along with listening comprehension, fear of speaking, and unfamiliarity with Western conversational styles. Samovar et al. (2006) stated that the subject of eye contact is very important one which causes miscommunication between Asians and Westerners. They perceived American students ignoring them due to a lack of eye contact or eye contact which was deemed too intense, or changes in discussion topics which were too fast or took place without signaling turns or interrupting them during discussions. These factors are related to conversational styles such as turn-taking. This source of culturally related anxiety is associated with the notions of "the flow of talk" (p. 288), "exchanges of turns" (p. 288) as stated in Wong-Scollon and Scollon's (1990) study which summarized that English and Chinese conversation styles are different. As Klopf (1997) and Wong-Scollon and Scollon (1990) noted Chinese speakers demand respectful participation, and as $\mathrm{Hu}$ and Grove (1991) stated Chinese are taught to be humble and not to be assertive in speech. Also, some of these participants viewed their American professors as not being able to 
understand Taiwanese students' cultural and educational background and accept them as second-language speakers. Other sources involved competitiveness and mixed feelings among Taiwanese students and the lack of training in listening comprehension and group discussion due to Taiwanese educational practices. These sources of anxiety and adjustment are all related to one another.

Some factors may overlap into two categories, as they relate to both language anxiety and cultural components of adjustment such as the unfamiliar practice of group discussion in class which is associated with the culture of the classroom. This factor may be said to involve both cultural adjustment and language anxiety. This can also be true for the interpretation of nonverbal signals, such as eye contact, from American students which has been found to make these participants feel uncomfortable and the language anxiety arising from not being able to comprehend what American classmates say or effectively participate during group discussions, which is related to an unfamiliarity with Western conversational styles. This anxiety is found to be culturally related and can be called culturally-related language anxiety.

The results from this study can be readily related to a number of definitions and claims offered in the previous research on language anxiety. De's fear of making errors when speaking English and Chan's high self-consciousness before speaking are consistent with Foss and Reitzel's (1988) concept of language anxiety as being similar to communication anxiety.

Two of the participants (i.e., De and Ai) are college-level English instructors in Taiwan who have experienced high or moderately high language anxiety. This finding is consistent with Horwitz's (1996; 2000) argument that even advanced and successful language learners such as English instructors experience language anxiety.

Based on the results, almost all of the participants stated that they have experienced strong anxiety during in-class group discussions. This is consistent with the results of Pappamihiel's (2002) study, which claimed that that language anxiety is closely associated to interaction between the language learners and the target language speakers in social situations.

Price's (1991) study found that language students' fear of making mistakes is one of the primary reasons for their language anxiety, and this finding is consistent with the findings of the current study. Half of the participants indicated that a fear of speaking in class is associated with their anxiety, and of these, three of them explicitly expressed a fear of making errors when speaking in class. Ehrman and Oxford's (1995) study identified similar concerns among learners about making errors or expressing themselves clearly as a significant factor in language learning. This finding in the current study also partially confirmed the results of Mak's (2011) study on first-year university students' FL speaking-in-class anxiety in Hong Kong, which found that speech anxiety, fear of speaking in English classes, is the most important factor contributing to the anxiety.

Not being able to comprehend what American professors or American students are saying in class is also significantly associated with their language anxiety. One participant set high standards for herself-i.e., she made a goal to comprehend completely everything said in English. This perfectionism can intensify a learner's language anxiety over making mistakes. This, too, has been identified in the literature. For instance, Price's (1991), Gregersen and Horwitz's (2002), and Hilleson's (1996) studies all showed that language learners' high anxiety can be related to over-concern over performing without flaws. This also brings to mind Horwitz et al.'s (1986) and Horwitz's (1988) studies, which concluded that the primary source of language anxiety is students' belief in the necessity of high levels of target language accuracy.

Almost all of the participants reported having a hard time participating in group discussions in the U.S. The primary reasons include that they are not used to the classroom format (i.e., group discussions), speaking in class, Americans' speech rate, and perceived Americans' attitudes towards them including eye contact and conversational styles such as turning taking. This finding is partly consistent with Zhou et al.'s (2005) study on Chinese graduate students studying in Canada, which concluded that they seldom participate in class due to their unfamiliarity with the interaction format in Canada and the lack of background knowledge of Canadian culture. This finding is inconsistent with Young's (1990) and Suwantarathip and Wichadee's (2010) study which concluded that students who work in small groups experience low anxiety.

To cite one detail involving classroom format, some participants reported having experienced high language anxiety when called on in class by their professors. This finding is identified in Young's (1990) study, which concluded that having students volunteer to answer questions is better than calling on them individually in class, as the latter practice may cause their anxiety level to go up. Finally, seven of these participants' mixed feelings toward and perceived competition among other members of the same nationality is also partly consistent with Bailey's (1983) findings among learners. 


\section{Limitation and Recommendation}

The findings of this study lack generalization due to the small number of participants and the qualitative nature of the study. Other studies of this nature will be necessary to gauge the results of similar samples in similar contexts. The results of this study found that participating in group discussions as one of the primary factors associating with language anxiety and adjustment. As a result, there is a need for future research on foreign students' culturally-related language anxiety, especially in relation to in group discussions and especially in consideration of non-verbal communication and target-language conversational styles.

\section{References}

Aida, Y. (1994). Examination of Horwitz, Horwitz, and Cope's construct of foreign language anxiety: The case of students of Japanese. The Modern Language Journal, 78(2), 155-168. http://dx.doi.org/10.1111/j.1540-4781.1994.tb02026.x

Bailey, K. M. (1983). Competitiveness and anxiety in adult second language learning: Looking at and through the diary studies. In H. W. Seliger, \& M. H. Long (Eds.), Classroom oriented research in second language acquisition (pp. 67-103). Rowley, MA: Newbury House.

Casado, M. A., \& Dereshiwsky, M. I. (2004, March). Effect of educational strategies on anxiety in the second language classroom: An exploratory comparative study between U. S. and Spanish first-semester university students. College Student Journal, 38(1), 23-36.

Clément, R. (1980). Ethnicity, contact, and communicative competence in a second language. In H. Giles, W. P. Robinson, \& P. M. Smith (Eds.), Language: Social psychological perspectives (pp. 147-154). Oxford: Pergamon.

Clément, R., Dörnyei, Z., \& Noels, K. A. (1994, September). Motivation, self-confidence, and group cohesion in the foreign language classroom. Language Learning, 44(3), 417-448. http://dx.doi.org/10.1111/j.1467-1770.1994.tb01113.x

Cohen, Y., \& Norst, M. J. (1989). Fear, dependence, and loss of self-esteem: Affective barriers in second language learning among adults. RELC Journal, 20, 61-77. http://dx.doi.org/10.1177/003368828902000206

Constantine, M. G., Okazaki, S., \& Utsey, S. O. (2004). Self-concealment, social self-efficacy, acculturative stress, and depression in African, Asian, and Latin American international college students. America Journal of Orthopsychiatry, 74(3), 230-241. http://dx.doi.org/10.1037/0002-9432.74.3.230

Denzin, N. K., \& Lincoln, Y. S. (Eds.). (2003). Collecting and interpreting qualitative materials. (2nd ed.). Thousand Oaks, CA: Sage.

Ehrman, M. E., \& Oxford, R, L. (1995). Cognition plus: Correlates of language learning success. The Modern Language Journal, 79(1), 67-89. http://dx.doi.org/10.1111/j.1540-4781.1995.tb05417.x

Fontana, A., \& Frey, J. H. (2003). The interview: From structured questions to negotiated text. In N. K. Denzin, \& Y. S. Lincoln (Eds), Collecting and interpreting qualitative materials (2nd ed., pp. 61-106). Thousand Oaks, CA: Sage.

Foss, K. A., \& Reitzel, A. C. (1988). A relational model for managing second language anxiety. TESOL Quarterly, 22(3), 437-454. http://dx.doi.org/10.2307/3587288

Gardner, R. C., \& MacIntyre, P. D. (1993). A student's contribution to second language learning: Part II, affective factors. Language Teaching, 26, 1-11. http://dx.doi.org/10.1017/S0261444800000045

Gregersen, T., \& Horwitz, E. K. (2002). Language learning and perfectionism: Anxious and non-anxious language learners' reactions to their own oral performance. The Modern Language Journal, 86(4), 562-270. http://dx.doi.org/10.1111/1540-4781.00161

Gullahorn. J. T., \& Gullahorn, J. E. (1963). An extension of the U-curve hypothesis. Journal of Social Issues, 19(3), 33-47. http://dx.doi.org/10.1111/j.1540-4560.1963.tb00447.x

Hall, E. T. (1976). Beyond Culture. New York, NY: Doubleday.

Hewitt, E., \& Stephenson, J. (2012). Foreign language anxiety and oral performance: A replication of Phillips's $\begin{array}{llllll}\text { MLJ study. Modern } & \text { Language }\end{array}$ http://dx.doi.org/10.1111/j.1540-4781.2011.01174.x

Hilleson, M. (1996). "I want to talk with them, but I don't want them to hear": An introspective study of second language anxiety in an English-medium school. In K. M. Bailey, \& D. Nunan (Eds.), Voices from the 
language classroom: Qualitative research in second language education (pp. 248-275). Cambridge: Cambridge University Press.

Horwitz, E. K. (1988). The beliefs about language learning of beginning university foreign language students. The Modern Language Journal, 72(3), 283-294. http://dx.doi.org/10.1111/j.1540-4781.1988.tb04190.x

Horwitz, E. K. (1996). Even teachers get the blues: Recognizing and alleviating language teachers' feelings of foreign language anxiety. Foreign Language Annuals, 29(3), 365-372. http://dx.doi.org/10.1111/j.1944-9720.1996.tb01248.x

Horwitz, E. K. (2000, June). It ain’t over 'til it's over: On foreign language anxiety, first language deficits, and the confounding of variables. Modern Language Journal, 84(2), 256-259. http://dx.doi.org/10.1111/0026-7902.00067

Horwitz, E. K., Horwitz, M. B., \& Cope, J. A. (1986). Foreign language classroom anxiety. In E. K. Horwitz, \& D. J. Young (Eds.), Language anxiety: From theory and research to classroom implications (pp. 27-36). Englewood Cliffs, NJ: Prentice-Hill.

Horwitz, E. K., \& Young, D. J. (1991). Language anxiety: From theory and research to classroom implications. Englewood Cliffs, NJ: Prentice-Hill.

Hu, W., \& Grove, C. (1991). Encountering the Chinese: A guide for Americans. Yarmouth, ME: Intercultural Press.

Liu, M., \& Jackson, J. (2008). An exploration of Chinese EFL learners' unwillingness to communicate and foreign language anxiety. The Modern Language Journal, 92(i), 71-86. http://dx.doi.org/10.1111/j.1540-4781.2008.00687.x

Kim, M. (2002). Non-western perspectives on human communication: Implications for theory and practice. Thousand Oaks, CA: Sage.

Klein, M. H., Alexander, A. A., Tseng, K., Miller, M. H., Yeh, E., Chu, H., \& Workneh, F. (1971). The foreign student adaptation program: Social experiences of Asian students in the U.S. International Educational And Cultural Exchange, 6(3), 77-90.

Klopf, D. W. (1997). Cross-cultural apprehension research: Procedures and comparisons. In J. A. Daly, J. C. McCroskey, J. Ayres, T. Hopf, \& D. M. Ayres (Eds.), Avoiding communication: Shyness, reticence, and communication apprehension (2nd ed., pp. 269-284). Beverly Hills, CA: Sage.

Krueger, R. A. (1993). Quality control in focus group research. In D. L. Morgan (Ed.), Successful focus groups: Advancing the state of the art (pp. 65-85). Thousand. Oaks, CA: Sage. http://dx.doi.org/10.4135/9781483349008.n5

Leary, M. R. (1982). Social anxiety. In L. Wheeler (Ed.), Review of personality and social psychology 3 (pp. 97-120). Beverly Hills, CA: Sage.

Lim, H.-Y. (2009). Culture, attributions, and language anxiety. Applied Language Learning, 19(1), 29-52.

MacIntyre, P. D. (1995). How does anxiety affect second language learning? A reply to Sparks and Ganschow. The Modern Language Journal, 79(1), 90-99. http://dx.doi.org/10.1111/j.1540-4781.1995.tb05418.x

MacIntyre, P. D. (1999). Language anxiety: A review of the research for language teachers. In D. J. Young (Ed.), Affect in foreign language and second language learning: A practical guide to creating a low-anxiety classroom atmosphere (pp. 24-45). Boston, MA: McGraw-Hill.

MacIntyre, P. D., \& Gardner, R. C. (1991, March). Methods and results in the study of anxiety and language learning: A review of the literature. Language Learning, 41(1), 85-117. http://dx.doi.org/10.1111/j.1467-1770.1991.tb00677.x

Mak, B. (2011). An exploration of speaking-in-class anxiety with Chinese ESL learners. System, 39, 202-214. http://dx.doi.org/10.1016/j.system.2011.04.002

Martin, J. N., \& Nakayama, T. K. (2008). Experiencing intercultural communication: An introduction (3rd ed.). New York, NY: McGraw-Hill.

Maxwell, J. A. (1996). Qualitative research design: An interactive approach. Thousand Oaks, CA: Sage.

McCroskey, J. C. (1977). Classroom consequences of communication apprehension. Communication Education, 26, 27-33. http://dx.doi.org/10.1080/03634527709378196 
Merriam, S. B. (1988). Case study research in education: A qualitative approach. San Francisco, CA: Jossey-Bass.

Mesri, F. (2012). The relationship between gender and Iranian EFL learners' foreign language classroom anxiety (FLCA). International Journal of Academic Research in Business and Social Sciences, 2(6), 147-156.

Mills, N., Pajares, F., \& Herron, C. (2006). A reevaluation of the role of anxiety" self-efficacy, anxiety, and their relation to reading and listening proficiency. Foreign Language Annuals, 39(2), 276-295. http://dx.doi.org/10.1111/j.1944-9720.2006.tb02266.x

Pappamihiel, N. E. (2002, February). English as a second language students and English language anxiety: Issues in the mainstream classroom. Research in the Teaching of English, 36, 327-355.

Patton, M. Q. (1990). Qualitative evaluation and research methods (2nd ed.). Newbury Park, CA: Sage.

Pavlenko, A. (2002, April 1). Narrative study: Whose story is it, anyway? TESOL Quarterly, 36(2), 213-218. http://dx.doi.org/10.2307/3588332

Price, M. L. (1991). The subjective experience of foreign language anxiety: Interviews with highly anxious students. In E. K. Horwitz, \& D. J. Young (Eds.), Language anxiety: From theory and research to classroom implications (pp. 101-107). Englewood Cliffs, NJ: Prentice-Hill.

Samovar, L. A., Porter, R. E., \& McDaniel, E. R. (2006). Communication between cultures (6th ed.). Belmont, CA: Thomson Wadsworth.

Stake, R. E. (1995). The art of case study research. Thousand Oaks, CA: Sage.

Stroud, C., \& Wee, L. (2006). Anxiety and identity in the language classroom. RELC Journal, 37(3), 299-307. http://dx.doi.org/10.1177/0033688206071311

Suwantarathip, O., \& Wichadee, S. (2010). The impacts of cooperative learning on anxiety and proficiency in an EFL class. Journal of College Teaching \& Learning, 7(11), 51-57.

Swagler, M. A., \& Ellis, M. V. (2003). Crossing the distance: Adjustment of Taiwanese graduate students in the $\begin{array}{lllll}\text { United States. Journal of Counseling Psychology, 50(4), 420-437. } & \text {. }\end{array}$ http://dx.doi.org/10.1037/0022-0167.50.4.420

Wang, C., \& Mallinckrodt, B. (2006). Acculturation, attachment, and psychosocial adjustment of Chinese/Taiwanese international students. Journal of Counseling Psychology, 53(4), 422-433. http://dx.doi.org/10.1037/0022-0167.53.4.422

Wong-Scollon, S., \& Scollon, R. (1990). Epilogue to “Athabaskan-English interethnic communication.” In D. Carbaugh (Ed.), Cultural communication and intercultural contact (pp. 287-290). Hillsdale, NJ: Erlbaum.

Young, D. J. (1990, December). An investigation of students' perspectives on anxiety and speaking. Foreign Language Annuals, 23(6), 539-555. http://dx.doi.org/10.1111/j.1944-9720.1990.tb00424.x

Young, D. J. (1999). Affect in foreign language and second language learning: A practical guide to creating a low-anxiety classroom. In D. J. Young (Ed.), Affect in foreign language and second language learning: A practical guide to creating a low-anxiety classroom atmosphere (pp. 3-9). Boston, MA: McGraw-Hill.

Zhou, Y. R., Knoke, D., \& Sakamoto, I. (2005). Rethinking silence in the classroom: Chinese students' experiences of sharing indigenous knowledge. International Journal of Inclusive Education, 9(3), 287-311. http://dx.doi.org/10.1080/13603110500075180

\section{Copyrights}

Copyright for this article is retained by the author(s), with first publication rights granted to the journal.

This is an open-access article distributed under the terms and conditions of the Creative Commons Attribution license (http://creativecommons.org/licenses/by/3.0/). 